sciendo Zagreb International Review of Economics \& Business, Vol. 23, Special Conference Issue, pp. 43-56, 2020 (C) 2020 Faculty of Economics and Business, University of Zagreb and De Gruyter Open

All rights reserved. Printed in Croatia ISSN 1331-5609; UDC: $33+65$

DOI: 10.2478 /zireb-2020-0022

CONFERENCE PAPER

\title{
Balance of Payments Deficit and Currency Board Arrangement Sustainability in Bosnia and Herzegovina
}

\author{
Siniša Kurtěs * \\ Srđan Amidžic * \\ Perica Rajčević ${ }^{* *}$
}

\begin{abstract}
Constant current account deficit in Bosnia and Herzegovina results from a large foreign trade imbalance, which in turn is a consequence of uncompetitiveness of the economy in the global market. The current account deficit is mainly financed by foreign remittances, foreign aid, and least of all by foreign investment. Lately, the outflow of the active, working population has been decreasing the labor force (especially the qualified and highly educated employees), as well as the domestic demand, which will exert further pressure on the balance of payments account. On the other hand, monetary policy is operating under the principles of currency board, i.e. applying a firm exchange rate, so the question arises whether and to what extent it is sustainable, under the conditions of a high current account deficit. The purpose of this paper is precisely to examine the relation between the deficit of balance of payments and the sustainability of the currency board arrangement in Bosnia and Herzegovina, under such conditions.
\end{abstract}

Keywords: current account; currency board; balance of payments deficit

JEL Classification: A10, E24, E42, F43

\section{Introduction}

With the outset of the 2008 global financial and economic crisis, the focus of attention of economic discussions was once more on monetary policy. In recent decades, while the global economy was recording high growth rates, the impact of monetary policy was losing importance. The accent was primarily on fiscal policy. Otherwise,

\footnotetext{
${ }^{*}$ Siniša Kurteš and Srđan Amidžić are at University of Banja Luka, Faculty of Economics, Bosnia and Herzegovina, E-mails: sinisa.kurtes@ef.unibl.org; srdjan.amidzic@ef.unibl.org

*** Perica Rajčević is at Vodovod a.d. Banja Luka, Bosnia and Herzegovina,E-mail: prajcevic@yahoo.com
} 
the concept that used to prevail in the economic doctrine in the end of the last and beginning of the current century was advocating monetary policy, with the main purpose of price stabilization. That sends positive signals to both the economy and the population. Therefore, monetary policy was not playing a significant role in ensuring economic growth and development. However, due to the great financial and economic crisis of 2008, a growing number of countries was using monetary policy instruments to alleviate its consequences. Otherwise, it is a known fact that whenever the world was caught in a crisis, be it financial or economic, the resolution was most frequently an expansionary monetary policy. Nowadays, many countries are reexamining the role of monetary policy, seeking optimum solutions to encourage economic growth and development. This drives us to consider also the appropriateness of monetary policy in Bosnia and Herzegovina, bearing in mind that it is conducted under the strict principles of currency board.

The purpose of the paper is to analyze the role of the currency board, i.e. the requirements for its sustainability under the conditions of balance of payments deficit, and to present proposal solutions which would lead in a medium- and long-term to the improvement of the balance of payments of Bosnia and Herzegovina. $\mathrm{BiH}$ suffers from enormous foreign trade and balance of payments deficits, relatively low foreign investment and small productivity growth, which is why the question is often asked in the public whether more could have been done with a flexible exchange rate and autonomous monetary policy. By definition, a currency board provides financial (price) stability and it is conducive to investment. On the other hand, literature often states that the absence of a discretionary monetary policy is paid for by lower growth rates and higher unemployment rates. However, performance of the currency boards in Estonia and Hong Kong refuted completely these theoretical posits. Estonia, for example, during the 1995-2010 period, managed to achieve high growth rates with a relatively low unemployment rates, thus contesting for the most part the dogma about the price of currency board. The question is why Estonia, with a currency board arrangement, is practically the most successful among the transition countries of Eastern Europe, and $\mathrm{BiH}$ is at the bottom of all transition-related lists.

\section{Characteristics of the Central Bank of Bosnia and Herzegovina}

The monetary policy of Bosnia and Herzegovina is operating under the principles of currency board, i.e. there is no classical central bank with discretionary powers to conduct monetary policy. So, it is in a currency board system which is mainly diametrically opposite to a system represented by classical central banking. The following overview best shows the differences between a currency board such as the one in force in $\mathrm{BiH}$ and a classical central bank: 
Table 1: Differences between a classical central bank system and currency board concept

\begin{tabular}{|c|c|c|}
\hline & \multicolumn{2}{|c|}{ Currency board arrangement vs classical central bank } \\
\hline & Currency board arrangement & Central bank \\
\hline 1. & Supplies only banknotes and coins & Supplies banknotes, coins and deposits \\
\hline 2. & Fixed exchange rate to reserve currency & Fixed or floating exchange rate to reserve currency \\
\hline 3. & $\begin{array}{l}\text { Foreign exchange reserves at the level of } 100 \% \text { of } \\
\text { monetary liabilities }\end{array}$ & Variable foreign exchange reserves \\
\hline 4. & $\begin{array}{l}\text { Full convertibility } \\
\end{array}$ & Limited convertibility \\
\hline 5. & Monetary policy tied by strict rules & Discretionary monetary policy \\
\hline 6. & Not lender of the last resort for banks & Lender of the last resort for banks \\
\hline 7. & Not regulating commercial banks & Has the role of commercial bank regulator \\
\hline 8. & Transparent & Transparent \\
\hline 9. & Partly protected from political pressure & Possible political influence \\
\hline 10. & High credibility of the system & Bank credibility susceptible to fluctuations \\
\hline 11. & Generates seigniorage from interest & Generates seigniorage from interest \\
\hline 12. & Cannot finance spending by domestic authorities & May finance spending by domestic authorities \\
\hline 13. & Needs no conditions for monetary reform & Needs conditions for monetary reform \\
\hline 14. & Fast monetary reform & Slow monetary reform \\
\hline 15. & Cannot affect inflation rate trending & $\begin{array}{c}\text { May create inflationary pressures or influence its } \\
\text { decrease }\end{array}$ \\
\hline 16. & $\begin{array}{c}\text { Small staff - human resource capacity in line with } \\
\text { smaller scope of work }\end{array}$ & $\begin{array}{l}\text { Large staff - larger human resource capacity in } \\
\text { line with larger scope of work }\end{array}$ \\
\hline
\end{tabular}

Source: Authors, based on data from www.cbbh.ba

Bosnia and Herzegovina, as a small and open economy with war legacy, opted, at the suggestions from the international community, to conduct a monetary policy based on the principle of currency board. The currency board system is based on a monetary institution with full convertibility of the domestic currency, at a permanently fixed exchange rate. The specificity of $\mathrm{BiH}$ indicates this option as fair, bearing in mind past experiences with monetary institutions, i.e. with the level of local knowledge of monetary policy management, which was very often causing the state of hyperinflation that has impoverished further the population of entire Bosnia and Herzegovina.

Monetary policy is one of the key instruments of stabilization policy to fortify prosperity in a country. As one of the key basic objectives of monetary and economic policies, achieving price stability is the best thing that a central bank can do to boost economic growth and financial stability. Once the monetary policy has restrained inflation successfully, a favorable economic environment can be deemed created for a sound market competition. Those objectives could only be achieved in $\mathrm{BiH}$ by introducing a currency board, which represents the most rigorous form of fixed tying of the exchange rate. The concept of currency board is aimed at avoiding abuses by the state, individual political and interest groups and central bank itself, creating the 
preconditions to ensure price and currency stability, establishing convertibility and economic policy credibility, enhancing foreign trade, savings and investment, attracting foreign banks, achieving financial integration with developed countries etc.

Since the introduction of the currency board until present, we may conclude that the initially set goals have been largely met. The currency board in $\mathrm{BiH}$ has provided stability, especially regarding: annual inflation level, real GDP, interest rate, fiscal balance and foreign exchange reserves. The main advantage of the currency board is that it establishes firm rules which prevent economic policy creators issuing money without backing, and lending directly to the state, banks and companies.

However, the major shortcoming of a currency board system is demonstrated in case of balance of payments deficit, when money supply shrinks, which may produce the consequence of recessionary effects (Vladušić 2010). Such monetary policy exposes the economy of the country using the currency board system to the negative and positive shocks of the national economy of the state issuing the anchor currency (in this case - euro), which is added to also by the inability of the $\mathrm{CBBiH}$ to issue money and be the last resort for banks under the conditions of recession.

\section{Instruments of the Central Bank of Bosnia and Herzegovina}

Bearing in mind that the Central Bank of Bosnia and Herzegovina uses the rate of reserve requirement as the only monetary policy instrument available, it is necessary to present details of the results it has achieved over the past period.

\section{Experiences of Using Reserve Requirement in Bosnia and Herzegovina}

The Law on the Central Bank of BiH provides for this bank's power to 'formulate and control the monetary policy of $\mathrm{BiH}$ ' and its explicit objective 'to achieve and maintain the stability of the domestic currency'. Although the only instrument available to the $\mathrm{CBBiH}$ under the law is the reserve requirement level, the Bank appears neither in the role of banking system supervisor, nor as the lender of the last resort (Kondic 2004).

The reserve requirement has two main roles. The first is of prudential nature, since by regulating bank liquidity it supports the stability of the financial system, and the second is that it acts as an instrument of transmission of monetary policy measures to economic activity and inflation. Most frequently, economic theory lists two main lines of action by the reserve requirement rate on the economic activity and inflation, i.e. through impact on loan supply and control of foreign capital inflow. As to the first line of action, usually the starting point is credit channel theory (Bernanke, Blinder 1988). According to this theory, the reserve requirement affects economic activity 
and inflation by affecting the lending capacity of banks, i.e. through credit channel. Namely, increase in the reserve requirement rate influences reduction of bank loan supply and results in a slowdown of economic activity and a decline in inflation. The above is a theoretical representation of the influence to be achieved by the reserve requirement rate, but deviations are often in practice. Table 1 shows that excess funds above the reserve requirement deposited with the $\mathrm{CBBiH}$ were exceptionally high in all concerned periods. Therefore, the question arises as to how efficient an instrument of transmission is the reserve requirement rate and how much does it really affect the scope of lending to the economy and population, i.e. increase and decrease of banking system liquidity?

Table 2: Overview of trending of reserve requirement rate and excess above the reserve requirement by year, from 2004 to 2018

\begin{tabular}{|c|c|c|c|c|}
\hline Year & Reserve requirement rate & $\begin{array}{l}\text { Basis for reserve } \\
\text { requirement cal- } \\
\text { culation (in BAM } \\
\text { million) }\end{array}$ & $\begin{array}{l}\text { Average reserve } \\
\text { requirement (in } \\
\text { BAM million) }\end{array}$ & $\begin{array}{l}\text { Excess above re- } \\
\text { serve requirement } \\
\text { (in BAM million) }\end{array}$ \\
\hline 2004 & From $5 \%$ to $7.5 \%$ & 6596 & 406 & 655 \\
\hline 2005 & $10 \%$ & 8456 & 885 & 630 \\
\hline 2006 & $15 \%$ & 10905 & 1635 & 737 \\
\hline 2007 & $15 \%$ & 14328 & 2149 & 1160 \\
\hline 2008 & $18 \%$ until 11 October, $14 \%$ & 17320 & 2961 & 686 \\
\hline 2009 & $\begin{array}{l}14 \% \text { on funds with maturity up to } 1 \text { year } \\
10 \% \text { on funds with maturity over } 1 \text { year } \\
7 \% \text { on funds with maturity over } 1 \text { year } \\
\text { from } 01 \text { May }\end{array}$ & 16194 & 1754 & 1256 \\
\hline 2010 & $\begin{array}{l}14 \% \text { on funds with maturity up to } 1 \text { year } \\
7 \% \text { on funds with maturity over } 1 \text { year }\end{array}$ & 15617 & 1624 & 1529 \\
\hline 2011 & $\begin{array}{l}10 \% \text { on funds with maturity up to } 1 \text { year } \\
7 \% \text { on funds with maturity over } 1 \text { year }\end{array}$ & 15227 & 1324 & 1635 \\
\hline 2012 & $\begin{array}{l}10 \% \text { on funds with maturity up to } 1 \text { year } \\
7 \% \text { on funds with maturity over } 1 \text { year }\end{array}$ & 14757 & 1258 & 1453 \\
\hline 2013 & $\begin{array}{l}10 \% \text { on funds with maturity up to } 1 \text { year } \\
7 \% \text { on funds with maturity over } 1 \text { year }\end{array}$ & 15162 & 1290 & 1813 \\
\hline 2014 & $\begin{array}{l}10 \% \text { on funds with maturity up to } 1 \text { year } \\
7 \% \text { on funds with maturity over } 1 \text { year }\end{array}$ & 15999 & 1370 & 2207 \\
\hline 2015 & $\begin{array}{l}10 \% \text { on funds with maturity up to } 1 \text { year } \\
7 \% \text { on funds with maturity over } 1 \text { year }\end{array}$ & 16664 & 1432 & 2338 \\
\hline 2016 & $\begin{array}{l}10 \% \text { on funds with maturity up to } 1 \text { year } \\
7 \% \text { on funds with maturity over } 1 \text { year }\end{array}$ & 18494 & 1734 & 2323 \\
\hline 2017 & $10 \%$ & 21224 & 2122 & 2181 \\
\hline 2018 & $10 \%$ & 23537 & 2354 & 2851 \\
\hline
\end{tabular}

Source: Authors, based on $\mathrm{CBBiH}$ data 
Research such as (Amidžić et al. 2019) has demonstrated that there is no significant correlation between the trending of the reserve requirement rate and the level of loans provided, i.e. that the reserve requirement rate has not proved to be an efficient instrument, except in the domain of improving liquidity of the overall banking sector. Namely, the reserve requirement is at the same time the only and the strong tool for macroprudential intervention and support to the liquidity of the banking sector in a situation in which there is no developed money market, or possibility to borrow from the Central Bank, as the case is in BiH. During the period of escalation of the latest global financial crisis in October of 2008, the banks in BiH suffered a mini bank run, when about 800 million of citizen deposits were withdrawn, i.e. almost $15 \%$ of the savings at the time. Intervention of the Central Bank of Bosnia and Herzegovina consisted of an emergency transfer of 200 million euro in cash from abroad to domestic banks. Moreover, in October 2008, the Central Bank of Bosnia and Herzegovina reduced the reserve requirement rate from $18 \%$ to $14 \%$, thus ensuring further 727 million BAM of liquid funds. These measures practically preserved the trust in the then still very fragile $\mathrm{BiH}$ financial system.

\section{Requirements for Currency Board Sustainability}

Successful maintenance of a fixed exchange rate regime requires a firm commitment by competent authorities, as well as fulfilment of certain preconditions, in terms of consistency of the exchange rate policy, freedom of movement of capital and restrictive use of monetary policy instruments. When a country is applying a currency board arrangement, the macroeconomic framework should ensure fiscal policy prudence, sound financial system, external debt level management and flexible labor market. If there is a serious imbalance of one of those elements from the macro level, that is a clear indicator of potential vulnerability and danger for the currency board arrangement (Guide et al. 2000). Furthermore, external vulnerability of the macroeconomic system stems from the external pressure on $\mathrm{BiH}$ economy through: exchange rate and foreign exchange reserves, balance of payments deficit and limited potential to amortize external pressures under the conditions of currency board.

The control of sustainability of the existing BiH monetary system is best tested by analyzing previous pressures on it, as follows:

- restrictions to capital movement,

- trending of major economic indicators,

- productivity growth, i.e. gross value added (GVA) per employee.

Bearing in mind that, until present, restricting free flow of capital to $\mathrm{BiH}$ has shown no negative impact on the set parity between the euro and the convertible mark, we may conclude that the currency board in $\mathrm{BiH}$, thus far, has fulfilled the preconditions for system sustainability. 
Until present, the $\mathrm{CBBiH}$ has adopted only the objectives that are in line with its ultimate intent of maintaining the parity relation between the euro and BAM. Additionally, it endeavors also to achieve other implicit objectives, using exclusively the instrument of reserve requirement, as allowed under the currency board arrangement. Therefore, the $\mathrm{CBBiH}$ is acting as a passive intermediary in conducting the monetary policy;

- Almost full liberalization of capital movement between $\mathrm{BiH}$ and foreign countries has been established.

Based on the data presented in the following table, it can be observed that the currency board, in accordance with theoretical expectations, has played the role of anchor and enabled firm budget constraint, as reflected in fiscal discipline and absence of higher fiscal deficits, except in the crisis year of 2009. Moreover, it provided a relatively low share of public debt in GDP, not exceeding $41 \%$ at any moment, although this period saw acknowledgment of more than 3 billion BAM of internal debt (this primarily concerns old foreign currency savings and 'war damage'), which were not being recorded at all before 2007, and $\mathrm{BiH}$ was not publishing data on public indebtedness at all. As of 31 December 2018, BiH Entities, as parties responsible for those liabilities, had successfully repaid more than 2.5 billion BAM of these liabilities and current standing of unpaid liabilities on those grounds is about 630 million BAM. That allows us to state that during the past period, the currency board was successful in meeting the Maastricht convergence criteria regarding fiscal policy and public debt, and in that regard, no serious risks have been noted until present.

On the other hand, it is clear that there is still a significant imbalance regarding foreign trade partners, as reflected in the high current account deficit. One may freely say that this poses a major threat to the sustainability and stability of the currency board system. This problem is further aggravated by knowing that the current account deficit was created as a result of an enormous deficit in trade in goods, and that until present it was mainly financed on the basis of remittances from abroad. Those remittances are an unstable source of financing, as reflected by the following data. For example, foreign remittances in 2008 covered the current deficit in the amount of $26.84 \%$ (CBBIH 2008), which is alarming as 2.5 billion BAM inflow generated on that basis that year do not represent real production in $\mathrm{BiH}$. The above amount depends solely on the emotions and desires of our people working abroad, as well as on their economic strength which is subject to fluctuations. The research from 2016 (Amidzic et al.) showed that the remittances and aid during the 2011-2014 period were constantly ranging between $13.66 \%$ and $14.18 \%$ of BiH GDP. Opinions are divided in professional literature regarding efficiency and effectiveness of remittances, but one point of more or less general agreement is that remittances have a positive social dimension, a negative political dimension (they postpone necessary reforms) and a questionable economic dimension. Remittances in $\mathrm{BiH}$ influence improvement, i.e. reduce poverty and increase disposable income of the population receiving them, be- 
cause those remittances mainly finance consumption, rather than investment. Their large share is direct aid intended for consumption in daily lives of the families and their relatives. The other part flows into construction and finances construction of the houses and apartments intended to serve the working migrants in the future, once they retire, as residence. Therefore, the main economic effects are covering the negative balance in trade in goods, as lion's share of the funds ends up in purchasing imported consumer goods, and labor market distortion, because people receiving aid from their relatives are not willing to accept the wages that the market can offer at given level of productivity.

Table 3: Indicators of currency board vulnerability

\begin{tabular}{|c|c|c|c|c|c|}
\hline & $\begin{array}{c}\text { Fiscal deficit (\%) } \\
\text { GDP }\end{array}$ & $\begin{array}{c}\text { Current account } \\
\text { deficit (\%) GDP }\end{array}$ & $\begin{array}{c}\text { Public debt (\%) } \\
\text { GDP }\end{array}$ & $\begin{array}{c}\text { Inflation rate } \\
\text { CPI \% }\end{array}$ & Growth rate GDP \\
\hline 2005 & 2.3 & -16.6 & n/a & 3.8 & n/a \\
\hline 2006 & 2.7 & -7.6 & n/a & 6.1 & 5.4 \\
\hline 2007 & 1.1 & -9.1 & 40.4 & 1.5 & 5.9 \\
\hline 2008 & -2.1 & -13.8 & 29.9 & -0.4 & 5.4 \\
\hline 2009 & -4.3 & -6.4 & 34.4 & 2.1 & -3.0 \\
\hline 2010 & -2.4 & -6.0 & 38.6 & 3.7 & 0.9 \\
\hline 2011 & -1.2 & -9.5 & 39.3 & 2.1 & -0.8 \\
\hline 2012 & -2.0 & -8.6 & 39.7 & -0.1 & 2.4 \\
\hline 2013 & -2.2 & -5.3 & 39.7 & -0.9 & 1.1 \\
\hline 2014 & -2.0 & -7.2 & 40.85 & -1 & 3.1 \\
\hline 2015 & 0.7 & -5.1 & 42.86 & -1.1 & 3.1 \\
\hline 2016 & 1.2 & -4.7 & 39.78 & 1.2 & 3.2 \\
\hline 2017 & 2.6 & -4.3 & 35.6 & 1.4 & 3.6 \\
\hline 2018 & 2.3 & -3.7 & 32.9 & & \\
\hline
\end{tabular}

Source: Central Bank of BiH and Ministry of Finance and Treasury of BiH

One of the requirements for credibility of a currency board arrangement is stability and soundness of the financial sector. First, it is important to verify the coverage of major monetary aggregates by foreign exchange reserves of the $\mathrm{CBBiH}$, which is a key requirement for credibility of a currency board arrangement. 
Table 4. Indicators of currency board sustainability

\begin{tabular}{|c|c|c|c|}
\hline Year & $\begin{array}{c}\text { Gross foreign reserves in } \\
\text { million BAM }\end{array}$ & $\begin{array}{c}\text { Reserve money (M0) coverage } \\
\text { by foreign reserves in (\%) }\end{array}$ & $\begin{array}{c}\text { Broad money (M2) coverage } \\
\text { by foreign reserves in (\%) }\end{array}$ \\
\hline 2005 & 4224 & 106.3 & 49.1 \\
\hline 2006 & 5452 & 107.8 & 55.00 \\
\hline 2007 & 6699 & 107.5 & 56.00 \\
\hline 2008 & 6296 & 110.3 & 50.6 \\
\hline 2009 & 6212 & 110.00 & 48.87 \\
\hline 2010 & 6458 & 109.4 & 47.4 \\
\hline 2011 & 6424 & 109.8 & 44.55 \\
\hline 2012 & 6509 & 112.1 & 43.65 \\
\hline 2013 & 7068 & 110.4 & 43.91 \\
\hline 2014 & 7825 & 111.8 & 45.31 \\
\hline 2015 & 8606 & 113 & 46.1 \\
\hline 2016 & 9531 & 113.6 & 47.1 \\
\hline 2017 & 10557 & 111.2 & 47.73 \\
\hline 2018 & 11623 & 111.8 & 48 \\
\hline
\end{tabular}

Source: Central Bank of $\mathrm{BiH}$

$\mathrm{CBBiH}$ foreign reserves were recording significant growth and following the dynamics of monetary aggregates. That way, the coverage of reserve money (M0) was stable, and even exceeding the required $100 \%$, while the median coverage in the case of broad money (M2) was $47.55 \%$. Therefore, it may be concluded that there is no potential risk for currency board sustainability from this aspect.

The key requirement for currency board arrangement sustainability under the conditions of a high current account deficit is to prevent erosion of competitiveness of $\mathrm{BiH}$ economy at international level, as that might lead to further aggravating of the deficit and consequently bring currency board arrangement into danger. Since money and capital movement have been mainly liberalized, with a strictly set BAM to euro exchange rate, the convergence of the inflation rate is part of the 'impossible trinity'. In a currency board arrangement, inflation rate, measured by the cost of living index or retail prices, paints a partly wrong picture due to a high level of import. That is why it is important to consider inflationary pressures arising from labor costs, i.e. on supply-side economics.

Simply put, a necessary precondition for sustainability of the exchange rate, and thereby also of the currency board arrangement, is that productivity (GVA, gross value added per employee, L) does not grow slower than gross employee wages (W) in an economy, i.e.:

\section{$\Delta G V A / L \geq \Delta W$}

The importance of this requirement should be understood in the following way: if gross wages grow faster than productivity, consumption will grow above the current 
income of individuals, which would cause a higher import growth and stimulate inflationary pressures on the one hand, and eventually lead to export decline. Together, this would cause aggravation in the current account deficit and bring into question the sustainability of the euro-BAM parity, and thereby also of the currency board arrangement itself.

Basically, as long as productivity does not grow slower than wages, there is no danger for the sustainability of the euro-BAM parity from this aspect. This requirement derives from Robert Mundell's macroeconomic model of adjustments in case of fixed and flexible exchange rate, where dynamics of economic growth and wage flexibility can be set as key requirements for sustainability of a fixed exchange rate. To support the above assertions also by theory, diagram number 1 explains precisely the very essence of maintaining the stability of currency board.

Diagram 1: Requirements for maintenance of currency board stability (Robert Mundell model)

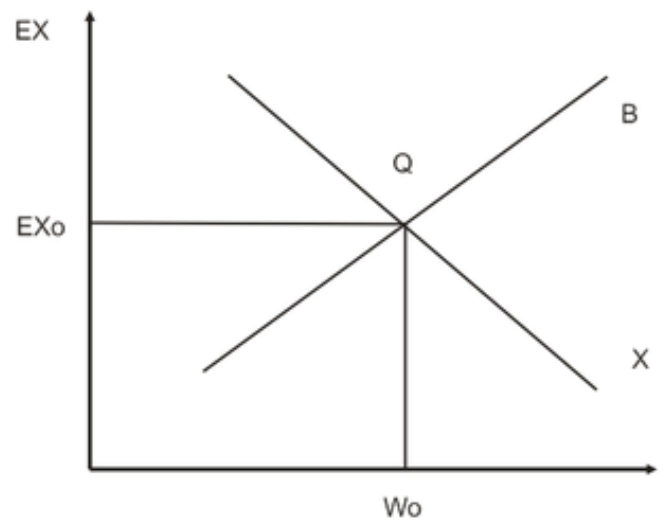

Source: Mundell, R., (1961), A Theory of Optimum Currency Areas, The American Economic Review No. 51.

EX denotes exchange rate, where upward movement means appreciation of the domestic currency. W symbolizes wages or salaries which are ranging from the lower level shown on the left-hand side to the higher level shown on the right-hand side. The $X$ line represents internal equilibrium, i.e. full employment (not necessarily zero unemployment rate), while the B line represents external equilibrium, i.e. balance of payments equilibrium. Point $Q$ represents overall equilibrium at the exchange rate level EXo and wage level Wo. Any point to the southwest of X is in the zone of less than full employment, while in any point to the northeast of $X$, the level of employment is above the full employment level. Any point to the northwest of B is in the zone of balance of payments deficit, while southeast of B lies the zone of balance of payments surplus. In point $\mathrm{Q}$, wages and exchange rate are precisely sufficient to 
ensure simultaneous internal and external equilibrium. Assuming that EX is fixed, adjustments are then made only by changing the wages level. If, however, $\mathrm{W}$ is fixed, then exchange rate needs to be flexible in order to enable the adjustment. Obviously, both EX and W may be both flexible and fixed to a certain degree, and that way relative fixedness of EX and $\mathrm{W}$ quantities defines the adjustment mechanisms to be used (Mundell 1961).

This very model demonstrates the potential trap for the existing currency system in $\mathrm{BiH}$, because wages in the past period were growing faster than labor productivity. That is evident from the following table:

Table 4. Trending of $\mathrm{BiH}$ average gross wage and GVA per employee

\begin{tabular}{|c|c|c|c|c|}
\hline Year & $\begin{array}{c}\text { Number of employees } \\
\text { in BiH }\end{array}$ & $\begin{array}{c}\text { Gross value added per } \\
\text { employee in BAM }\end{array}$ & $\begin{array}{c}\text { Gross wages per } \\
\text { employee in BAM }\end{array}$ & Investment as GDP \% \\
\hline 2005 & 643988 & 23123 & 12413 & 26.90 \\
\hline 2006 & 654326 & 24321 & 13619 & 21.46 \\
\hline 2007 & 683629 & 26134 & 14975 & 24.74 \\
\hline 2008 & 706088 & 29413 & 17281 & 26.38 \\
\hline 2009 & 686044 & 29965 & 18213 & 18.89 \\
\hline 2010 & 683399 & 30472 & 18994 & 18.31 \\
\hline 2011 & 687917 & 31253 & 19279 & 18.32 \\
\hline 2012 & 685117 & 31327 & 19296 & 17.23 \\
\hline 2013 & 689270 & 32124 & 19196 & 17.46 \\
\hline 2014 & 707725 & 31822 & 19421 & 18.91 \\
\hline 2015 & 715425 & 32950 & 19141 & 20.44 \\
\hline 2016 & 737955 & 33422 & 19432 & 20.64 \\
\hline 2017 & 753202 & 34480 & 19197 & \\
\hline 2018 & 808627 & 34290 & & \\
\hline
\end{tabular}

Source: BiH Agency for Statistics

In the 2005-2018 time series, the average wage in $\mathrm{BiH}$ grew by $55 \%$, and at the same time GVA per employee grew by $48 \%$, which means that labor wages grew faster than the productivity. The above data indicate clearly that wage growth is not adequately covered by productivity growth in the economy, which directly influences faster growth of consumption, and thereby also the level of domestic prices and import growth. Furthermore, this leads to the appearance of the Balassa-Samuelson effect, which further degrades the country's competitive position by reducing export and increasing unemployment (Amidžic et al. 2016)

In this context, the relatively low level of gross investment given in the last column of Table 4 should be observed as another indirect consequence. In theory, gross investment in developing countries should be about $25 \%$ GDP in order to reduce the 
gap with developed countries. BiH had a satisfactory level of gross investment only in the short period before the latest global crisis, which was followed by a period of stagnation and reduced activity. For comparison purposes, the 2013 level of gross investment in the EU 28 was $19.6 \%$ GDP, and in BiH it was only $17.23 \%$ GDP, while the 2018 ratio was $21 \%$ GDP and $20.64 \%$ GDP, respectively.

All the above in itself does not mean that the currency board system is in danger, but it does mean that a threat exists and that it is outside the monetary sector in the labor market, in inefficient administration, oversized and unreformed public sector. The real problems are best perceived in the parameters of ease of doing business. For 2018, BiH ranked 86th among 190 countries (WB\&IFC, 2018), while in 2016 it was 79th among 189 countries (WB\&IFC, 2015). According to the 2015 Index of Economic Freedom, BiH ranked 97th among 178 countries and fell into the group of mostly unfree countries in terms of economic freedom (The Heritage Foundation, 2015). The IMF Working Paper (201/19) clearly indicates that problem generator is the public sector, focusing on state-owned enterprises which are a source of illiquidity, inefficiency and distortionary action on the existing labor market.

\section{Conclusion}

There are several possibilities to alleviate or prevent further negative impact on the competitiveness of $\mathrm{BiH}$ economy, i.e. on currency board arrangement sustainability. The first step to successful problem-solving is a properly established diagnosis, meaning that the source of economic problems in $\mathrm{BiH}$ are not the limitations of the currency board, but rather the structural disturbances and the oversized and inefficient public sector. Potential solutions can be sought in the following measures: reducing labor taxation, reducing taxes on reinvested profits, cutting employment in public administration and in particular rationalizing and privatizing the state-owned enterprises sector. A common denominator for all possible solutions is the following: they are not simple, they are not fast solutions, they are not cheap for $\mathrm{BiH}$, and the last three are particularly unpopular with the public.

Labor taxation in $\mathrm{BiH}$ is currently the highest in the Western Balkan region, and through its reduction i.e. fiscal devaluation, $\mathrm{BiH}$ might expect both improvement in its competitive position, and equalization of growth rates of wages and productivity.

Tax reduction, i.e. elimination of the tax on reinvested profits would encourage private investment in $\mathrm{BiH}$, and through financial leverage it would in turn boost engagement of the funds currently parked with the $\mathrm{CBBiH}$ in the form of funds exceeding the reserve requirement. We have already stated that without the growth of gross investment to about $25 \%$ GDP, it would not be possible to reduce seriously the gap with the EU countries. We deem that only spending the excess reserve requirement on investment can ensure the growth of gross investment of 300/400 basis points of 
GDP. The funds are there, but stimuluses and plans for their activation have evidently been lacking until present.

Reduction of spending in the public sector imposes itself as a possible solution, primarily through reduction of employment both at the state and the Entity level. Administrative bodies at the state and Entity levels have not only failed to demonstrate readiness of any kind for spending cuts, but they have persisted in their demands for new and larger funding. The essence of the problem is partly in financing of the joint bodies, which do not depend on the dynamics and level of collected funds, but exclusively on the adopted budget framework, which is certainly a unique solution in the world. It is precisely the users of the budget and public funds that have not made any effort whatsoever to reduce public spending, and that is where the greatest opportunities for cuts lie. Although the population has been constantly dwindling, the number of employees in public administration, education and healthcare services has grown during this period by more than $15 \%$, which is in direct opposition to the efforts to increase GVA per employee.

Completion of the processes of transition and privatization of state-owned enterprises imposes itself as a 'conditio sine qua non' if there is desire to stop the downward spiraling which generates illiquidity in the economy, inefficiency of public investment and distortion of the labor market.

Bearing in mind basic shortcomings of the present system, such as high unemployment, low rate of economic growth and enormous foreign trade deficit, as well as the advantages reflected in price stability and credibility of the monetary system, the above measures, accompanied by export stimulation and more realistic planning of revenues and expenditures at all levels, have no alternative, if $\mathrm{BiH}$ wishes to catch up with the EU countries.

\section{REFERENCES}

Agency for Statistics of $\mathrm{BiH}$, various annual publications.

Amidžić S., Rajčević, P., Kurteš, S., (2016) The Competiveness in the Light of the Balassa-Samuelsson Effect on Bosnia and Herzegovina, 9th International Conference on Social Sciences ICSS IX, Dubrovnik

Amidžić, S., Rajčević, P., Kurteš, S., (2019) Obavezna rezerva kao instrument monetarnog regulisanja - iskustvo Bosne i Hercegovine, Banja Luka: Financing 2

Berrnanke B. and A. S. Blinder (1988), Credit, Money, and Aggregate Demand, American Economic Review 78,

Berrnanke B. and A. S. Blinder (1988), Credit, Money, and Aggregate Demand, American Economic Review 78,

Berrnanke B. and A. S. Blinder (1988), Credit, Money, and Aggregate Demand, American Economic Review 78,

Bernnake, B., Blinder, A.S., (1988) Credit Money and Aggregate Demand, American Economic Review 78 . 
Dušanić, J., Špirić, N., (2009) Monetarne i javne finasije, Ekonomski fakultet Banja Luka.

CB BiH Annual Report for 2010.

IMF (2019) Working paper 201/19

Kondić, N., (2004) Monetarni sistemi, Ekonomski fakultet Banja Luka.

Kozarić K., (2009) Utjecaj globalne financijske krize na Bosnu i Hercegovinu; Centralna banka Bosne i Hercegovine.

Kristić, I., (2007), Održivost aranžmana valutnog odbora u BiH, Sarajevo.

Mundell, R., (1961), A Theory of Optimum Currency Areas, The American Economic Review No. 51.

Rajčević, P., (2011), Uslovi održivosti aranžmana valutnog odbora u BiH, Banja Luka: Finrar. 11.

Tomaš, R., (2018) Makroekonomsko okruženje u Bosni i Hercegovini u funkciji razvoja biznisa - stanje i perspektive 8. Međunarodna naučno-stručna konferencija Razvoj poslovanja 2018: "EKONOMSKI IZAZOVI ZEMALJA U TRANZICIJI", Zenica.

Vilendečić, S., (2008), Monetarna politika, devizni kurs i monetarna unija, Banja Luka, Besjeda.

Vilendečić, S., (2004), Napuštanje sistema valutnog odbora u tranzicionim ekonomijama, Zavod za udžbenike i nastavna sredstva, Istočno Sarajevo.

Vladušić, Lj., (2010) Štednja i ekonomski rast u Bosni i Hercegovini, Ekonomski fakultet Istočno Sarajevo.

Law on Budget of $\mathrm{BiH}$ Institutions and International Obligations for 2010. Official Gazette of $\mathrm{BiH}$ $103 / 09$.

Law on the Central Bank of BiH, Dayton Peace Accords, Constitution of BiH, Article VII.

Law on the Indirect Taxation System in BiH, Official Gazette of BiH 44/03.

Web portals:

www.cbbh.ba

www.ecb.int

www.bhas.ba 